\title{
BMJ Open Prevalence and associated factors of lower extremity musculoskeletal disorders among manufacturing workers: a cross-sectional study in China
}

Xu Jin, ${ }^{1}$ Yidan Dong, ${ }^{1}$ Fujiang Wang, ${ }^{1}$ Ping Jiang, ${ }^{1}$ Zhongbin Zhang, ${ }^{2}$ Lihua He (D) , ${ }^{1}$ Mikael Forsman, ${ }^{3,4}$ Liyun Yang ${ }^{3,4}$

To cite: Jin $X$, Dong $Y$, Wang $F$, et al. Prevalence and associated factors of lower extremity musculoskeletal disorders among manufacturing workers: a cross-sectional study in China. BMJ Open 2022;12:e054969. doi:10.1136/ bmjopen-2021-054969

- Prepublication history for this paper is available online. To view these files, please visit the journal online (http://dx.doi. org/10.1136/bmjopen-2021054969).

$\mathrm{XJ}$ and $\mathrm{YD}$ are joint first authors.

Received 29 June 2021

Accepted 12 January 2022
Check for updates

(C) Author(s) (or their employer(s)) 2022. Re-use permitted under CC BY-NC. No commercial re-use. See rights and permissions. Published by BMJ.

For numbered affiliations see end of article.

Correspondence to

Dr Lihua He;

alihe2009@126.com

\section{ABSTRACT}

Objective To survey the prevalence of lower extremity musculoskeletal disorders (MSDs) among Chinese manufacturing workers, and to identify the associated factors.

Design Observational study with cross-sectional design. Setting A self-administered questionnaire survey was conducted in four manufacturing factories in China. Participants 7908 manufacturing workers were included in this study after excluding non-conforming personnel.

Outcome measures Individual and work-related information, and MSDs in the whole leg and knee region were measured by the anonymous self-administered questionnaire. Individual and work-related factors associated with MSDs and their effects were identified through multivariate logistic regression.

Results Of all respondents, 3241 (41.0\%) reported having had lower extremity MSDs in the recent 12 months, and for the knees, ankles/feet and hips/thighs were $29.5 \%$, $23.9 \%$ and $16.7 \%$, respectively. After confounderadjusted single-factor analysis, 22 variables (of 24) were significantly related to the disorders. Factors like always kneeling/squatting for long periods, always standing for long periods and often lifting in an uncomfortable position were shown to have higher risks, with ORs of $2.77(95 \%$ Cl: 2.33 to 3.30), 2.30 (1.96 to 2.69) and 2.25 (2.04 to 2.47). Comparable results were found on knee disorders. The final model included 15 variables of demography, biomechanics and work organisation. The following factors showed increased risks of lower extremity MSDs: being female, being older, longer working years, higher body mass index (BMI), keeping the same posture for a long time, awkward position, shift work and monotonous work. Whereas having enough breaks reduced the risk. Conclusion The prevalence of lower extremity MSDs among Chinese manufacturing workers is high. The most commonly affected body regions were the knees and ankles/feet. Multiple factors were found associated with lower extremity MSDs including age, BMI, work experience, work organisations, physical ergonomics exposures, etc.
Strengths and limitations of this study

- This study focused on lower extremity musculoskeletal disorders (MSDs), which are important aspects of the occupational health but less investigated in the workplaces.

- This cross-sectional study included a large population with 7908 valid survey respondents from four manufacturing factories in China, and assessed multiple factors affecting lower extremity MSDs.

- The results of this study can help explore the association between multiple risk factors and lower extremity MSDs, and develop prevention strategies for reducing their risks.

- Recall bias may exist. The prevalence of MSDs may be overestimated by using questionnaires.

\section{INTRODUCTION}

Work-related musculoskeletal disorders (MSDs) are worldwide public health problems among occupational population, which affect a great number of workers from different occupations and bring huge economic burden to both individuals and society. ${ }^{12}$ Typical disorders like low back pain, neck pain and carpal tunnel syndrome have gained wide attention in both developed and developing countries. $^{3-5}$ Lower extremity MSDs, including pain in the knees, hips/ thighs and ankles/feet, are however less investigated, especially in developing countries. ${ }^{6} 7$

The prevalence of lower extremity MSDs is high among occupational population, causing immense burden to individuals, family and society. ${ }^{8}$ Lower extremity MSDs generate not only pain or discomfort, but also a limitation in daily activities. Serious pain and daily activity limitation have extensive impacts on the emotional state and quality of life of sufferers. ${ }^{9-11}$ Those with serious lower 
extremity MSDs may have to turn to walking sticks, wheelchairs or surgical operation, such as knee arthroplasty. The absenteeism and reduced work productivity caused by lower extremity MSDs also bring burden to the operation of factories. In a British study, knee disorders had at some time caused $14 \%$ of the men in the general population to be absent from work (median time lost over working life $=14$ days $).{ }^{12}$ An American article reported knee MSDs accounted for $7 \%$ of the MSD claims and $10 \%$ of the MSD cost in Washington State, and the mean number of fund claims was 2771 per year, averaging $\$ 20200$ per claim. ${ }^{13}$

Lower extremity MSDs have a multifactorial aetiology, and the risk factors may be summarised as individual factors, biomechanical factors, organisational factors and psychosocial factors. ${ }^{14-16}$ Lower extremity MSDs have been studied among workers from different occupations, such as construction workers, manufacturing workers, farmers, nurses, office workers, etc. ${ }^{16-18}$ Among these occupations, the manufacturing industry holds a large number of employees, which are characterised by repetitive tasks, heavy physical workload and relatively low income, especially in developing countries. During the economic globalisation, a large proportion of manufacturing industries have been transferred to developing countries. As one example, China, a large manufacturing country in the world, has over 100 million manufacturing workers. Accordingly, the problem of lower extremity MSDs is significant in the manufacturing industries of both developed and developing countries, and it needs more attention. Therefore, this study aimed to investigate the prevalence of lower extremity MSDs and identify the risk factors among manufacturing workers.

\section{METHODS}

\section{Patient and public involvement}

Patients and the public were not involved in the study.

\section{Study design and participants}

A cross-sectional study was conducted among workers from four manufacturing factories in the Henan and Hubei provinces, China. The study was based on a selfadministered survey through a Chinese-edition questionnaire with a focus on MSD studies. Researchers from two universities and an institute of Occupational Disease Prevention and Control collaborated to ensure that the questionnaires were hand delivered to manufacturing workers who signed the inform consent form and fulfilled the inclusion criteria (see below). The cluster sampling method was used in this study, and participants were selected under the uniform inclusion criteria: (1) at least 18 years old, (2) job experience (current position) $\geq 1$ year; (3) no trauma, rheumatism, tumour or other diseases affecting the musculoskeletal system; (4) informed consent of the participants. A total number of 8233 questionnaires were collected (95.4\% response rate), and a total of 7908 valid questionnaires remained after invalid questionnaires were excluded (91.7\% efficiency rate).

\section{Questionnaire}

The questionnaire used for evaluating MSDs and associated factors in this study was developed by Yang et al, ${ }^{19}$ which was based on the Nordic Musculoskeletal Questionnaire ${ }^{20}$ and the Dutch Musculoskeletal Questionnaire. ${ }^{21}$ It has been tested for reliability and validity. ${ }^{22}$

The questionnaire is composed of three parts. The first part concerns general information. It includes personal factors like age, gender, education level and job experience. The second part addresses the prevalence of MSDs, including 1-week prevalence, 12-month prevalence and prevalence after getting the employment. In this study, we focused on 12-month prevalence. The third part covers the exposure of occupational factors, including biomechanical factors, work organisation and management, and the physical environment. The biomechanical factors include working postures, lifting heavy objects, repetitive tasks and overexertion. The work organisation and management factors include working overtime, shift work and work control. The physical environment factors include temperature and working space.

The questionnaire includes both quantitative continuous variables (such as age, job experiences, height) and qualitative variables with two to four categories. Question such as 'Do you often lift heavy objects in an uncomfortable position?' had two options: yes or no. Question such as 'Do you often stand for long periods at work?' had four options: seldom/never, sometimes, often and almost always.

Before the field investigation, the investigators, who were composed of occupational health professionals, received training to ensure they were familiar with the contents of this questionnaire and survey techniques. During the field investigation, the questionnaires with a cover letter explaining the purposes of the study and the procedure were distributed to the participants. The participants were encouraged to complete the questionnaire in a certified, truthful and complete way.

\section{Case definition}

In this study, the case of lower extremity MSDs and knees disorders was defined as having ache, pain, discomfort, or limitation of activities in one or more parts of the whole leg and knee region, which lasted for more than 24 hours and were not relieved after rest, in the last year.

\section{Statistical analysis}

Descriptive statistics were used to describe demographic information of the respondents by using numbers and percentages (for categorical variables), means and SD (for normally distributed continuous variables), and median and quartile (for continuous variables which were not normally distributed).

Univariate binary logistic regression analysis was first used to obtain the demographic factors' association to lower extremity MSDs. The OR and the 95\% CI of each factor were calculated. 
Then, separately for each of the biomechanical and organisational factors, binary logistic regression analysis with ORs adjusted for gender, age, job experiences, body mass index (BMI) and workplace was carried out to explore potential work-related risk factors to lower extremity MSDs.

Additionally, knee MSDs were analysed separately, as knee MSDs had the highest prevalence among lower extremity MSDs.

Finally, a multivariate binary logistic regression model for lower extremity MSDs was constructed with stepwise selection technique (entry: $\mathrm{p}<0.05$, removal: $\mathrm{p}>0.10$ ). The factors which had statistical association $(\mathrm{p}<0.05)$ with lower extremity MSDs in a separate variable analysis were chosen as independent variables for multifactor analysis.

For categorical variables with three or four categories, such as education level and long periods standing, dummy variables were constructed. For better analysis and interpretation, continuous variables including age, job experience and BMI were transformed to categorical variables, and dummy variables were also made for them. The first or the lowest category was chosen as a reference group to estimate the OR values of other categories for most multicategorical variables except BMI, for which normal weight group (BMI $18.5-23.9 \mathrm{~kg} / \mathrm{m}^{2}$ ) was made as a reference.

The statistical tests were two sided with a significance level at $\mathrm{p}<0.05$. All statistical analyses were performed through SPSS V.20.0 (IBM) for Windows.

\section{RESULT}

A total of 7908 respondents came from four manufacturing factories: an electrical equipment manufacturing factory, an automobile factory, a shipyard and a steel machinery manufacturing factory. Among them, 6069 $(76.7 \%)$ workers were men, and 1839 (23.3\%) were women. The age of the study respondents was $36.2 \pm 8.5$ $($ mean $\pm \mathrm{SD})$ years. The mean BMI was $22.68 \pm 2.95 \mathrm{~kg} /$ $\mathrm{m}^{2}$. The median job experience with its quartile was 11.0 (5.0-18.0) years. The detailed group information was presented in table 1.

Among the respondents, 3241 (41.0\%) reported experiencing lower extremity MSDs in the previous 12 months, including the pain symptoms in knees, ankles/ feet and hips/thighs. The 12-month prevalence rates of pain in knees, hips/thighs and ankles/feet were 29.5\%, $16.7 \%$, and $23.9 \%$, respectively. The 12 -month prevalence rate of multisite ( $\geq 2$ sites) lower extremity MSDs was $18.5 \%$, which accounted for $45.1 \%$ of the sufferers of lower extremity pain.

For exploring the influencing factors of lower extremity MSDs and knee pain, a total of 24 potential variables were chosen as independent variables and analysed by binomial logistic regression separately. The results were categorised into three parts, including aspects of demography, biomechanics and work organisation, which were presented in tables 2 and 3. Among them, 22 variables

\begin{tabular}{ll}
\hline $\begin{array}{l}\text { Table 1 Demographic characteristics of the respondents } \\
\text { (N=7908) }\end{array}$ & N (\%) \\
\hline Characteristics & $6069(76.7)$ \\
\hline $\begin{array}{l}\text { Gender } \\
\text { Male }\end{array}$ & $1839(23.3)$ \\
\hline Female & \\
\hline Age & $957(12.1)$ \\
\hline $18-25$ & $2851(36.1)$ \\
\hline $26-35$ & $2897(36.6)$ \\
\hline $36-45$ & $1203(15.2)$ \\
\hline$>46$ & \\
\hline Education level & $1340(16.9)$ \\
\hline Middle school or below & $4478(56.6)$ \\
\hline High school & $2090(26.4)$ \\
\hline College/university or above & \\
\hline BMI (kg/m²) & $445(5.6)$ \\
\hline$<18.5$ & $5028(63.6)$ \\
\hline $18.5-23.9$ & $2095(26.5)$ \\
\hline $24-27.9$ & $340(4.3)$ \\
\hline$>28$ & \\
\hline Job experience (years) & $1917(24.2)$ \\
\hline$<5$ & $1577(19.9)$ \\
\hline $5-9$ & $1593(20.1)$ \\
\hline $10-14$ & $2821(35.7)$ \\
\hline$>15$ & \\
\hline BM body mas index. & \\
\hline
\end{tabular}

BMI, body mass index.

were significantly correlated to lower extremity MSDs $(p<0.05)$, of which 5 variables were supposed to be protective factors with $\mathrm{OR}<1$, and the rest of the variables were supposed to be risk factors with OR $>1$. The separate analysis on knee pain showed similar results.

The logistic regression model for lower extremity MSDs was developed by 23 variables, of which 22 were selected from single-factor analysis with $\mathrm{p}<0.05$. Although gender showed no statistical significance in the single-factor analysis, considering its significance in previous relevant studies, it was still included in the regression analysis. Finally, 15 variables entered into the regression model by forward selection method, and the regression result was presented in table 4 .

Among demographic factors, gender, age, job experience and BMI entered into the regression model. Women seemed to have higher risk of lower extremity MSDs than men $(\mathrm{OR}=1.34, \mathrm{p}<0.001)$. Age older than 46 years seemed to be a risk factor compared with age group 18-25 years $(\mathrm{OR}=1.55, \mathrm{p}<0.001)$. Job experiences equal to 5 years or longer appeared to be a risk factor. Overweight (BMI: $\left.>24 \mathrm{~kg} / \mathrm{m}^{2}\right)$ seemed to be a risk factor $(\mathrm{OR}=1.20$, $\mathrm{p}<0.001)$. In the aspect of biomechanics, almost always standing for long periods seemed to increase the risk of 
Table 2 Results of univariate logistic regression analysis for the association between demographic factors and MSDs

\begin{tabular}{|c|c|c|c|c|}
\hline \multirow[b]{2}{*}{ Characteristics } & \multicolumn{2}{|l|}{ Knee MSDs } & \multicolumn{2}{|c|}{ Lower extremity MSDs } \\
\hline & Prevalence (\%) & OR (95\% Cl) & Prevalence (\%) & OR (95\% Cl) \\
\hline \multicolumn{5}{|l|}{ Demographic factors } \\
\hline \multicolumn{5}{|l|}{ Gender } \\
\hline Male & 29.7 & 1 & 40.9 & 1 \\
\hline Female & 28.6 & 0.95 (0.85 to 1.07$)$ & 41.3 & $1.02(0.91$ to 1.13$)$ \\
\hline \multicolumn{5}{|l|}{ Age (years) } \\
\hline$<18-25$ & 27.1 & 1 & 35.9 & 1 \\
\hline $26-35$ & 27.9 & 1.04 (0.88 to 1.23$)$ & 41.0 & $1.24(1.06 \text { to } 1.44)^{\star}$ \\
\hline $36-45$ & 29.2 & 1.11 (0.94 to 1.31$)$ & 40.9 & $1.24(1.06 \text { to } 1.47)^{\star}$ \\
\hline$>46$ & 36.0 & $1.52(1.26 \text { to } 1.82)^{\star *}$ & 45.1 & $1.46(1.23 \text { to } 1.74)^{* *}$ \\
\hline \multicolumn{5}{|l|}{ Education level } \\
\hline Middle school or below & 31.6 & 1 & 41.6 & 1 \\
\hline High school & 30.1 & 0.93 (0.81 to 1.06$)$ & 42.3 & $1.03(0.91$ to 1.17$)$ \\
\hline College/university or above & 26.9 & $0.80(0.68 \text { to } 0.92)^{\star *}$ & 37.8 & $0.85(0.74 \text { to } 0.98)^{*}$ \\
\hline \multicolumn{5}{|l|}{$\mathrm{BMI}\left(\mathrm{kg} / \mathrm{m}^{2}\right)$} \\
\hline$<18.5$ & 30.1 & 1.11 (0.90 to 1.37$)$ & 40.4 & 1.05 (0.87 to 1.28$)$ \\
\hline $18.5-23.9$ & 27.9 & 1 & 39.3 & 1 \\
\hline $24-27.9$ & 32.5 & $1.24(1.11 \text { to } 1.38)^{\star *}$ & 44.1 & $1.21(1.10 \text { to } 1.35)^{\star *}$ \\
\hline$>28$ & 33.2 & $1.28(1.02 \text { to } 1.62)^{\star}$ & 47.1 & $1.37(1.10 \text { to } 1.71)^{\star *}$ \\
\hline \multicolumn{5}{|l|}{ Job experience (years) } \\
\hline$<5$ & 24.2 & 1 & 34.0 & 1 \\
\hline $5-9$ & 28.2 & $1.23(1.06 \text { to } 1.43)^{\star *}$ & 41.9 & $1.40(1.22 \text { to } 1.61)^{\star \star}$ \\
\hline $10-14$ & 31.5 & $1.44(1.24 \text { to } 1.67)^{\star \star}$ & 42.6 & $1.45(1.26 \text { to } 1.65)^{\star \star}$ \\
\hline$>15$ & 32.7 & $1.52(1.33 \text { to } 1.73)^{\star *}$ & 44.3 & $1.55(1.37 \text { to } 1.75)^{\star *}$ \\
\hline
\end{tabular}

${ }^{*} \mathrm{P}<0.05,{ }^{* *} \mathrm{p}<0.01$.

BMI, body mass index; MSDs, musculoskeletal disorders.

lower extremity MSDs $(\mathrm{OR}=1.36, \mathrm{p}<0.001)$. After adjustment for other factors, often and almost always sitting for long period seemed to be risk factors, of which the OR values were 1.21 and 1.33 , respectively. Often and almost always kneeling/squatting for long period seemed to be risk factors, of which the OR values were 1.24 and 1.69 , respectively. Walking for long periods also appeared to be a risk factor. Often lifting in an uncomfortable position, often lifting with one hand and often performing short, maximal force exertions were also biomechanics variables, which seemed to be risk factors $(O R>1)$. In the aspect of the organisation, four variables entered into the model. Often working overtime, having shift work and doing the same work almost every day appeared to be risk factors with $\mathrm{OR}>1$, and feeling breaks were sufficient seemed to be a protective factor $(\mathrm{OR}=0.70, \mathrm{p}<0.001)$.

\section{DISCUSSION}

In this study, we investigated the prevalence of lower extremity MSDs among Chinese manufacturing workers, and assessed multiple factors associated with lower extremity MSDs.

The 12-month prevalence of lower extremity MSDs in this study was $41.0 \%$, which was higher than the result of a large cross-sectional study in Europe in 2016 (16.5\% for men, $15.8 \%$ for women). ${ }^{23}$ The difference in prevalence between the two studies is likely mirroring a higher prevalence among manufacturing workers, but often similar questionnaires from different studies show different prevalence, even when performed in the same occupation. This study focused on manufacturing workers, while respondents in the European study came from multiple industries. In the lower extremity MSD research of the manufacturing industry, the recent studies mainly come from developing countries, which may be related to the industrial chain transfer brought by economic globalisation. In a study in a Bangladesh garment factory, the 12-month prevalence rates of MSDs in hips/thighs, knees and ankles/feet were $2.5 \%, 17.7 \%$, and $9.5 \% .{ }^{24}$ In a survey on seafood processing plants in Vietnam, 53.3\% of female employees suffer from MSDs. ${ }^{25}$ According to a 
Table 3 Results of univariate logistic regression analysis for the association between work-related factors and MSDs

Knee MSDs

Lower extremity MSDs

Characteristics

Prevalence (\%)

OR $(95 \% \mathrm{Cl})$

Prevalence (\%)

OR $(95 \% \mathrm{Cl})$

Biomechanical factors*

Long periods standing

$\begin{array}{lllll}\text { Seldom/never } & 22.6 & 1 & 32.1 & 1 \\ \text { Sometimes } & 22.6 & 1.01(0.83 \text { to } 1.22) & 33.3 & 1.05(0.89 \text { to } 1.25) \\ \text { Often } & 27.8 & 1.36(1.14 \text { to } 1.63)^{\star \star} & 39.5 & 1.46(1.24 \text { to } 1.71)^{\star *} \\ \text { Almost always } & 37.4 & 2.16(1.81 \text { to } 2.57)^{\star \star} & 50.2 & 2.30(1.96 \text { to } 2.69)^{\star \star}\end{array}$

Long periods sitting

$\begin{array}{lllll}\text { Seldom/never } & 31.1 & 1 & 42.6 & 1 \\ \text { Sometimes } & 26.9 & 0.82(0.72 \text { to } 0.93)^{\star \star} & 38.4 & 0.81(0.72 \text { to } 0.92)^{\star \star} \\ \text { Often } & 25.3 & 0.75(0.64 \text { to } 0.89)^{\star \star} & 36.7 & 0.73(0.63 \text { to } 0.85)^{\star \star} \\ \text { Almost always } & 28.8 & 0.88(0.74 \text { to } 1.04) & 39.1 & 0.82(0.70 \text { to } 0.96)^{\star}\end{array}$

Long periods kneeling/squatting

$\begin{array}{lllll}\text { Seldom/never } & 24.4 & 1 & 35.3 & 1 \\ \text { Sometimes } & 29.2 & 1.31(1.15 \text { to } 1.49)^{\star \star} & 41.6 & 1.34(1.19 \text { to } 1.51)^{\star \star} \\ \text { Often } & 35.8 & 1.75(1.49 \text { to } 2.04)^{\star \star} & 48.9 & 1.86(1.60 \text { to } 2.16)^{\star *} \\ \text { Almost always } & 49.3 & 3.03(2.55 \text { to } 3.61)^{\star \star} & 58.7 & 2.77(2.33 \text { to } 3.30)^{\star \star} \\ \text { Long periods walking } & & & 36.1 & 1 \\ \text { No } & 25.7 & 1 & 45.9 & 1.54(1.40 \text { to } 1.69)^{\star *} \\ \text { Yes } & 33.3 & 1.48(1.33 \text { to } 1.63)^{\star \star} & \end{array}$

Often lifting heavy objects $(\mathrm{kg})$

$\begin{array}{lllll}<5 & 23.4 & 1 & 34.6 & 1 \\ 5 \sim & 29.2 & 1.38(1.21 \text { to } 1.56)^{\star *} & 41.6 & 1.38(1.23 \text { to } 1.54)^{\star *} \\ 20 \sim & 39.1 & 2.16(1.91 \text { to } 2.44)^{\star *} & 49.8 & 1.96(1.75 \text { to } 2.19)^{\star *}\end{array}$

Often lifting in uncomfortable positions

\begin{tabular}{|c|c|c|c|c|}
\hline No & 23.2 & 1 & 33.7 & 1 \\
\hline Yes & 39.9 & $2.19(1.97 \text { to } 2.42)^{\star *}$ & 52.9 & $2.25(2.04 \text { to } 2.47)^{\star \star}$ \\
\hline \multicolumn{5}{|c|}{ Often lifting with one hand } \\
\hline No & 25.5 & 1 & 35.9 & 1 \\
\hline Yes & 37.7 & $1.70(1.53 \text { to } 1.89)^{\star *}$ & 51.3 & $1.88(1.70 \text { to } 2.07)^{\star \star}$ \\
\hline \multicolumn{5}{|c|}{ Load is difficult to grasp/hold } \\
\hline No & 24.5 & 1 & 35.8 & 1 \\
\hline Yes & 39.8 & $2.02(1.82 \text { to } 2.24)^{\star *}$ & 51.6 & $1.94(1.75 \text { to } 2.14)^{\star \star}$ \\
\hline \multicolumn{5}{|c|}{ Often exerting great force on tools/machine } \\
\hline No & 24.5 & 1 & 35.6 & 1 \\
\hline Yes & 38.8 & $1.95(1.75 \text { to } 2.16)^{* *}$ & 50.8 & $1.88(1.70 \text { to } 2.07)^{\star *}$ \\
\hline \multicolumn{5}{|c|}{ Often performing short, maximal force exertions } \\
\hline No & 22.2 & 1 & 32.4 & 1 \\
\hline Yes & 36.4 & $2.06(1.86 \text { to } 2.29)^{\star \star}$ & 40.9 & $2.07(1.88 \text { to } 2.27)^{\star \star}$ \\
\hline \multicolumn{5}{|c|}{ Work organisation factors ${ }^{*}$} \\
\hline \multicolumn{5}{|c|}{ Often working overtime } \\
\hline No & 23.7 & 1 & 32.9 & 1 \\
\hline Yes & 32.9 & $1.70(1.52 \text { to } 1.89)^{* *}$ & 45.8 & $1.79(1.62 \text { to } 1.98)^{\star *}$ \\
\hline \multicolumn{5}{|c|}{ Shift work } \\
\hline No & 28.4 & 1 & 39.1 & 1 \\
\hline Yes & 31.6 & $1.26(1.13 \text { to } 1.41)^{\star \star}$ & 45.0 & $1.33(1.20 \text { to } 1.47)^{\star *}$ \\
\hline
\end{tabular}


Table 3 Continued

\begin{tabular}{|c|c|c|c|c|}
\hline \multirow[b]{2}{*}{ Characteristics } & \multicolumn{2}{|l|}{ Knee MSDs } & \multicolumn{2}{|c|}{ Lower extremity MSDs } \\
\hline & Prevalence (\%) & OR $(95 \% \mathrm{Cl})$ & Prevalence (\%) & OR $(95 \% \mathrm{Cl})$ \\
\hline \multicolumn{5}{|c|}{ Having sufficient breaks } \\
\hline Yes & 20.3 & $0.50(0.44 \text { to } 0.56)^{\star \star}$ & 30.2 & $0.51(0.46 \text { to } 0.56)^{\star \star}$ \\
\hline \multicolumn{5}{|c|}{ Can choose the start and end of a work day } \\
\hline Yes & 24.0 & $0.69(0.60 \text { to } 0.79)^{\star *}$ & 34.6 & $0.70(0.62 \text { to } 0.79)^{\star *}$ \\
\hline \multicolumn{5}{|c|}{ Can choose the time of a break } \\
\hline No & 30.9 & 1 & 42.7 & 1 \\
\hline Yes & 25.1 & $0.73(0.65 \text { to } 0.83)^{\star \star}$ & 35.8 & $0.73(0.66 \text { to } 0.81)^{\star \star}$ \\
\hline \multicolumn{5}{|c|}{ Having to replace workmates often } \\
\hline No & 25.2 & 1 & 33.2 & 1 \\
\hline Yes & 30.2 & $1.34(1.16 \text { to } 1.56)^{\star *}$ & 42.3 & $1.50(1.31 \text { to } 1.71)^{\star \star}$ \\
\hline \multicolumn{5}{|c|}{ Rotation between workers } \\
\hline No & 29.3 & 1 & 40.5 & 1 \\
\hline Yes & 29.8 & 1.02 (0.92 to 1.13$)$ & 41.7 & 1.05 (0.96 to 1.16$)$ \\
\hline \multicolumn{5}{|c|}{ Always working at the same place } \\
\hline No & 29.8 & 1 & 39.5 & 1 \\
\hline Yes & 29.4 & $1.03(0.92$ to 1.15$)$ & 41.5 & $1.12(1.01 \text { to } 1.24)^{\star}$ \\
\hline
\end{tabular}

${ }^{*} \mathrm{P}<0.05,{ }^{* *} \mathrm{p}<0.01$.

${ }^{*}$ Factors have been adjusted for gender, age, job experiences, BMI and workplace.

$\mathrm{BMI}$, body mass index; MSDs, musculoskeletal disorders.

survey on MSDs of a steel plant workers in Iran, the prevalence rates of MSDs in hips/thighs, knees and ankles/ feet were $18.0 \%, 47.8 \%$ and $21.6 \%{ }^{26}$ From these studies, we can conclude that lower extremity MSDs generally are prevalent among manufacturing workers. Most studies find prevalence rates between $10 \%$ and $50 \%$. The level of prevalence of lower extremity MSDs in our study population was in the middle of that interval.

In comparison with male gender, female gender has been suggested as a risk factor of MSDs in many studies, ${ }^{11} 2728$ while the difference was not found by a single-factor analysis in this study. Prevalence of MSDs in ankles/feet among women was even lower than men. However, this may be because factors such as workload can be considered as confounders in that comparison. In this study population, the female workers were generally exposed to a lower physical workload than the male workers in the plants. Accordingly, when putting gender into the final logistic regression, the result suggested that women had higher risk of lower extremity MSDs than men.

Workers belonging to the age group $\geq 26$ years, especially those older than 46 years, had a higher MSD risk than younger workers. This is consistent with the results of previous studies. ${ }^{89}$ In the context of ageing and the trend of postponing retirement age globally, more and more people might develop lower extremity MSDs, which is a problem worthy of consideration. We also found that with the increase of job experiences, the risk of lower extremity MSDs increases, which might be related to cumulative injury. Overweight $(\mathrm{BMI}>24)$ and obesity (BMI $>28$ ) were identified as risk factors. One probable explanation is that overweight and obesity lead to more loading on the bones, joints and soft tissues of the locomotor system of the lower extremities, including the hips, knees and ankles. ${ }^{30}$ Given the fact of global increase in obesity, interventions aiming at reducing BMI are interesting to decrease the MSDs among manufacturing workers. Still, for the working population, preventing obesity alone may not be sufficient for preventing MSDs; strategies on improving the work environment and the workload need to be combined. ${ }^{31}$

In this study, almost always standing for long periods might increase the risk of lower extremity MSDs, which concurred with the studies of Montano ${ }^{15}$ and Pensri et $a l .{ }^{32}$ Compared with seldom/never sitting for a long time, sometimes, often and almost always sitting for long periods were found protective factors, while multivariate logistic 
Table 4 Results of multivariate logistic regression analysis of lower extremity MSDs

\begin{tabular}{|c|c|c|c|c|c|}
\hline Variables & B & SE & Wald $X^{2}$ & $P$ value & OR $(95 \% \mathrm{Cl})$ \\
\hline Gender (refer to male) & 0.289 & 0.067 & 18.588 & $<0.001$ & 1.34 (1.17 to 1.52$)$ \\
\hline \multicolumn{6}{|l|}{ Age (years) } \\
\hline $18-25$ & & & 20.286 & $<0.001$ & \\
\hline $26-35$ & 0.114 & 0.100 & 1.303 & 0.256 & 1.12 (0.92 to 1.36$)$ \\
\hline $36-45$ & 0.090 & 0.108 & 0.696 & 0.404 & 1.09 (0.89 to 1.35$)$ \\
\hline$>46$ & 0.438 & 0.126 & 12.169 & $<0.001$ & 1.55 (1.21 to 1.98 ) \\
\hline \multicolumn{6}{|l|}{ Job experience (years) } \\
\hline$<5$ & & & 13.280 & 0.004 & \\
\hline $5-9$ & 0.219 & 0.083 & 6.853 & 0.009 & 1.24 (1.06 to 1.47 ) \\
\hline $10-14$ & 0.267 & 0.086 & 9.620 & 0.002 & 1.31 (1.10 to 1.55$)$ \\
\hline$>15$ & 0.291 & 0.088 & 10.858 & 0.001 & 1.34 (1.13 to 1.59$)$ \\
\hline \multicolumn{6}{|l|}{$\mathrm{BMI}\left(\mathrm{kg} / \mathrm{m}^{2}\right)$} \\
\hline$<18.5$ & 0.043 & 0.115 & 0.139 & 0.709 & 1.04 (0.83 to 1.31$)$ \\
\hline $18.5-23.9$ & & & 10.185 & 0.017 & \\
\hline $24-27.9$ & 0.179 & 0.061 & 8.497 & 0.004 & 1.20 (1.06 to 1.35$)$ \\
\hline$>28$ & 0.225 & 0.128 & 3.107 & 0.078 & 1.25 (0.98 to 1.61$)$ \\
\hline \multicolumn{6}{|l|}{ Long periods standing } \\
\hline Seldom/never & & & 26.673 & $<0.001$ & \\
\hline Sometimes & -0.018 & 0.098 & 0.035 & 0.852 & 0.98 (0.81 to 1.19$)$ \\
\hline Often & -0.004 & 0.099 & 0.001 & 0.970 & $1.00(0.82$ to 1.21$)$ \\
\hline Almost always & 0.307 & 0.100 & 9.490 & 0.002 & 1.36 (1.12 to 1.65$)$ \\
\hline \multicolumn{6}{|l|}{ Long periods sitting } \\
\hline Seldom/never & & & 10.598 & 0.014 & \\
\hline Sometimes & 0.026 & 0.069 & 0.146 & 0.703 & 1.03 (0.90 to 1.18$)$ \\
\hline Often & 0.190 & 0.087 & 4.743 & 0.029 & 1.21 (1.02 to 1.44$)$ \\
\hline Almost always & 0.283 & 0.098 & 8.301 & 0.004 & 1.33 (1.10 to 1.61$)$ \\
\hline \multicolumn{6}{|l|}{ Long periods kneeling/squatting } \\
\hline Seldom/never & & & 29.677 & $<0.001$ & \\
\hline Sometimes & 0.120 & 0.069 & 3.073 & 0.080 & 1.13 (0.99 to 1.29$)$ \\
\hline Often & 0.218 & 0.086 & 6.517 & 0.011 & 1.24 (1.05 to 1.47$)$ \\
\hline Almost always & 0.523 & 0.099 & 28.144 & $<0.001$ & 1.69 (1.39 to 2.05$)$ \\
\hline Long periods walking & 0.153 & 0.057 & 7.222 & 0.007 & 1.17 (1.04 to 1.30$)$ \\
\hline Often lifting in uncomfortable positions & 0.315 & 0.062 & 25.807 & $<0.001$ & 1.37 (1.21 to 1.55$)$ \\
\hline Often lifting with one hand & 0.269 & 0.060 & 19.911 & $<0.001$ & 1.31 (1.16 to 1.47$)$ \\
\hline Often performing short, maximal force exertions & 0.303 & 0.062 & 23.923 & $<0.001$ & 1.36 (1.20 to 1.53$)$ \\
\hline Often working overtime & 0.308 & 0.057 & 29.223 & $<0.001$ & 1.36 (1.22 to 1.52$)$ \\
\hline Shift work & 0.156 & 0.057 & 7.448 & 0.006 & 1.17 (1.05 to 1.31$)$ \\
\hline Having sufficient breaks & -0.368 & 0.059 & 39.300 & $<0.001$ & 0.70 (0.62 to 0.78$)$ \\
\hline Monotonous work & 0.231 & 0.079 & 8.615 & 0.003 & 1.26 (1.08 to 1.47$)$ \\
\hline
\end{tabular}

BMI, body mass index; MSDs, musculoskeletal disorders.

regression demonstrated that often and almost always sitting for long periods would increase the risk of lower extremity MSDs. One research from the USA showed that having the freedom to sit at work might prevent lower extremity MSDs. ${ }^{14}$ A South Korean cross-sectional study reported that sedentary behaviours might increase the risk of knee pain. ${ }^{33}$ These contradicting results might be concerned with the length and temporal pattern of sitting time, the inaccuracy or recall bias of the assessment method using a questionnaire, or the interacting effects 
of sitting and standing time, that is, within an 8-hour work day; an increased time in prolonged sitting would lead to a reduced time in standing/walking. In another way, MSDs in the lower extremities could lead to prolonged sitting because knee pain or other MSDs force the employee to sit. Hence, compared with 'seldom/never' sitting for long periods, the adjusted ORs of 'often' and 'almost always' sitting for long periods were 1.21 and 1.33 , respectively. Prolonged sitting had been thought as an unhealthy way of working by many researches, which could lead to a range of health problems, including MSDs. ${ }^{34-36}$ With the development of mechanisation and intelligence, sedentary work in the manufacturing industry is increasing as well. The following musculoskeletal diseases should be of concern. Consistent with many previous studies, ${ }^{29}{ }^{37}$ we found that prolonged squatting or kneeling might be a strong risk factor for lower extremity MSDs.

As in previous studies on lower extremity MSDs, ${ }^{29} 37$ we found that often lifting heavy materials $(\geq 5 \mathrm{~kg})$ might increase the risk of low extremity MSDs, especially lifting objects $\geq 20 \mathrm{~kg}$. Handling heavy materials means that lower extremities bear more biomechanical load. Factors related to manual material handling were also found to be risks, including often lifting in an uncomfortable position, lifting with one hand and grasping/holding a heavy load. These factors would increase the difficulty of material handling, and increase the force or make the force unbalanced which the lower extremities bore.

Many studies suggested that work organisation factors were associated with MSDs. Often working overtime was indicated to increase the risk of lower extremity MSDs in this study, ${ }^{38-41}$ which was reported in a previous study. ${ }^{42}$ Working overtime means increased exposure time to various loads and cumulative trauma. Feeling breaks were sufficient was found as a protective factor. Enough rest means that fatigue or trauma can be alleviated to some extent. Among three factors of job control, a degree of decision-making was indicated a protective factor, including: can choose the start and end of a work day and can choose the time of a break, whereas often having to replace workmates was supposed a risk factor. Insufficient control over work hours and rest means that one cannot make appropriate adjustments based on their physical condition. On the other hand, it might also affect the psychological condition of workers, bring negative emotions and indirectly lead to MSDs.

This study had a few limitations. As a cross-sectional study, the causal inference between lower extremity MSDs and related risk factors cannot be made; therefore, further cohort studies are needed. When using the questionnaires as the assessment method, recall bias might also affect the results because the case was defined as having the symptoms in the past 12 months, which could bring a certain degree of misclassification. For the classification of biomechanical work exposures, the words never/seldom, sometimes, often and almost always were used to describe corresponding frequencies. These words describe qualitative data, not quantitative data, which makes it difficult to compare with other studies. Also, the interpretation of these words might be different among different participants. Quantitative or semiquantitative frequency description should instead be used in the future.

\section{CONCLUSION}

This study showed a high 12-month prevalence of lower extremity MSDs among Chinese manufacturing workers. Of the lower extremities, the knees had the highest disorder prevalence. Several significant lower extremity MSD risk factors of different types were identified through the multivariate logistic regression analysis. Those were demographic factors, that is, being female, old age, long job experience, high BMI; biomechanical factors, such as prolonged time sitting, standing, kneeling/squatting and walking, and force factors such as lifting in uncomfortable positions, one-handed lifting and quick maximal force exertions; and work organisation factors, such as working overtime, shift work, insufficient breaks and monotonous work.

Although these risk factors were not surprising, it is a strength that they all have been identified in the same study. This should improve the confidence in these risks, and it should support manufacturing plants to make decisions, in a holistic way, that is, considering human capabilities, technical solutions and organisational factors, find and implement solutions to reduce these risks, to improve the health of the workers.

\section{Author affiliations}

${ }^{1}$ Department of Occupational and Environmental Health, School of Public Health, Peking University, Beijing, China

${ }^{2}$ National Center of Occupational Safety and Health, National Health Commission of the People's Republic of China, Beijing, China

${ }^{3}$ Institute of Environmental Medicine, Karolinska Institute, Stockholm, Sweden

${ }^{4}$ Division of Ergonomics, KTH Royal Institute of Technology School of Biotechnology, Stockholm, Sweden

Acknowledgements We would like to extend our appreciation to the National Musculoskeletal Disorders Research Cooperation Group for offering their assistance in data collection and entry.

Contributors XJ contributed to the conception of the article and results interpretation, drafted the manuscript and wrote the final paper with editing contributions from all coauthors. YD contributed to the conception of the article and results interpretation, and drafted the manuscript. FW contributed to the conception of the article and statistical analysis, and drafted the manuscript. PJ and ZZ contributed to the conception of the article and reviewed the results. LH contributed to the design of the study and reviewed the manuscript, and $\mathrm{LH}$ is the guarantor who accepts full responsibility for the finished work, had access to the data, and controlled the decision to publish. MF and $\mathrm{LY}$ reviewed and interpreted the results, and refined the final paper.

Funding This work is supported by the National Key Technologies Research \& Development Program (2016YFC0801700) and the Fundamental Research Funds for China Academy of Safety Science and Technology (2017JBKY02).

Competing interests None declared.

Patient and public involvement Patients and/or the public were not involved in the design, or conduct, or reporting, or dissemination plans of this research.

Patient consent for publication Not required.

Ethics approval This study involves human participants and was approved by the Ethics Committee of Peking University (IRB0000105216015). Participants gave informed consent to participate in the study before taking part. 
Provenance and peer review Not commissioned; externally peer reviewed.

Data availability statement Data are available upon reasonable request. Please refer to the corresponding author (alihe2009@126.com) for further information.

Open access This is an open access article distributed in accordance with the Creative Commons Attribution Non Commercial (CC BY-NC 4.0) license, which permits others to distribute, remix, adapt, build upon this work non-commercially, and license their derivative works on different terms, provided the original work is properly cited, appropriate credit is given, any changes made indicated, and the use is non-commercial. See: http://creativecommons.org/licenses/by-nc/4.0/.

ORCID iD

Lihua He http://orcid.org/0000-0002-4166-751X

\section{REFERENCES}

1 Bevan S. Economic impact of musculoskeletal disorders (MSDs) on work in Europe. Best Pract Res Clin Rheumatol 2015;29:356-73.

2 Mody GM, Brooks PM. Improving musculoskeletal health: global issues. Best Pract Res Clin Rheumatol 2012;26:237-49.

3 Hartvigsen J, Hancock MJ, Kongsted A, et al. What low back pain is and why we need to pay attention. Lancet 2018;391:2356-67.

4 Hoy D, March L, Woolf A, et al. The global burden of neck pain: estimates from the global burden of disease 2010 study. Ann Rheum Dis 2014;73:1309-15.

5 Dale AM, Harris-Adamson C, Rempel D, et al. Prevalence and incidence of carpal tunnel syndrome in US working populations: pooled analysis of six prospective studies. Scand J Work Environ Health 2013;39:495-505.

6 Yu S-fa, Gu G-zhen, Zhou W-hui, et al. [Association between occupational stress and musculoskeletal disorders in lower extremity]. Zhonghua Lao Dong Wei Sheng Zhi Ye Bing Za Zhi 2011;29:882-6.

7 Dorsey J, Bradshaw M. Effectiveness of occupational therapy interventions for lower-extremity musculoskeletal disorders: a systematic review. Am J Occup Ther 2017;71:1-11.

8 Mekonnen TH. The magnitude and factors associated with workrelated back and lower extremity musculoskeletal disorders among barbers in Gondar town, Northwest Ethiopia, 2017: a cross-sectional study. PLoS One 2019;14:e0220035.

9 MacKay C, Jaglal SB, Sale J, et al. A qualitative study of the consequences of knee symptoms: 'It's like you're an athlete and you go to a couch potato'. BMJ Open 2014;4:e006006.

10 Maruya K, Fujita H, Arai T, et al. Sarcopenia and lower limb pain are additively related to motor function and a history of falls and fracture in community-dwelling elderly people. Osteoporos Sarcopenia 2019;5:23-6.

11 Jhun H-J, Sung N-J, Kim SY. Knee pain and its severity in elderly Koreans: prevalence, risk factors and impact on quality of life. $J$ Korean Med Sci 2013;28:1807-13.

12 Baker P, Reading I, Cooper C, et al. Knee disorders in the general population and their relation to occupation. Occup Environ Med 2003;60:794-7.

13 Spector JT, Adams D, Silverstein B. Burden of work-related knee disorders in Washington state, 1999 to 2007. J Occup Environ Med 2011;53:537-47.

14 Messing K, Tissot F, Stock S. Distal lower-extremity pain and work postures in the Quebec population. Am J Public Health 2008;98:705-13.

15 Montano D. Upper body and lower limbs musculoskeletal symptoms and health inequalities in Europe: an analysis of cross-sectional data BMC Musculoskelet Disord 2014;15:285.

16 Gell N, Werner RA, Hartigan A, et al. Risk factors for lower extremity fatigue among assembly plant workers. Am J Ind Med 2011;54:216-23.

17 Andersen S, Thygesen LC, Davidsen M, et al. Cumulative years in occupation and the risk of hip or knee osteoarthritis in men and women: a register-based follow-up study. Occup Environ Med 2012;69:325-30.

18 Choi S, Jang SH, Lee $\mathrm{KH}$, et al. Risk factor, job stress and quality of life in workers with lower extremity pain who use video display terminals. Ann Rehabil Med 2018;42:101-12.

19 Yang L, Hildebrand V, Yu S. The introduction of a musculoskeletal disorders questionnaire-the questionnaire attached. . Industrial health and occupational diseases, 2009: 1. 25-31.
20 Kuorinka I, Jonsson B, Kilbom A, et al. Standardised Nordic questionnaires for the analysis of musculoskeletal symptoms. Appl Ergon 1987;18:233-7.

21 Hildebrandt VH, Bongers PM, van Dijk FJ, et al. Dutch musculoskeletal questionnaire: description and basic qualities. Ergonomics 2001;44:1038-55.

22 JB W, Peng BL, Ling RJ. Prevalence of elbow pain and its influence factors in welders of an automobile manufaturing enterprise. Chin $J$ Ind Med 2016;29:270-2.

23 Garcia M-G, Graf M, Läubli T. Lower limb pain among workers: a cross-sectional analysis of the fifth European working conditions survey. Int Arch Occup Environ Health 2017;90:575-85.

24 Hossain MD, Aftab A, Al Imam MH, et al. Prevalence of work related musculoskeletal disorders (WMSDs) and ergonomic risk assessment among readymade garment workers of Bangladesh: a cross sectional study. PLoS One 2018;13:e0200122.

25 Pham TC, Phan CTT, Pham TCThuy Thi Thu T,, et al. After-shift musculoskeletal disorder symptoms in female workers and workrelated factors: a cross-sectional study in a seafood processing factory in Vietnam. AIMS Public Health 2016;3:733-49.

26 Aghilinejad M, Choobineh AR, Sadeghi Z, et al. Prevalence of musculoskeletal disorders among Iranian steel workers. Iran Red Crescent Med J 2012;14:198-203.

27 DePalma MJ, Ketchum JM, Saullo TR. Multivariable analyses of the relationships between age, gender, and body mass index and the source of chronic low back pain. Pain Med 2012;13:498-506.

28 Bedno SA, Nelson DA, Kurina LM, et al. Gender differences in the associations of body mass index, physical fitness and tobacco use with lower extremity musculoskeletal injuries among new us army soldiers. Inj Prev 2019;25:295-300.

29 Herquelot E, Bodin J, Petit A, et al. Incidence of chronic and other knee pain in relation to occupational risk factors in a large working population. Ann Occup Hyg 2015;59:797-811.

30 Wearing SC, Hennig EM, Byrne NM, et al. Musculoskeletal disorders associated with obesity: a biomechanical perspective. Obes Rev 2006;7:239-50.

31 Viester L, Verhagen EALM, Hengel KMO, et al. The relation between body mass index and musculoskeletal symptoms in the working population. BMC Musculoskelet Disord 2013;14:1-9.

32 Pensri P, Janwantanakul P, Chaikumarn M. Biopsychosocial factors and musculoskeletal symptoms of the lower extremities of saleswomen in department stores in Thailand. J Occup Health 2010;52:132-41.

33 Lee S-H, Son C, Yeo S, et al. Cross-sectional analysis of selfreported sedentary behaviors and chronic knee pain among South Korean adults over 50 years of age in KNHANES 2013-2015. BMC Public Health 2019;19:1375.

34 van der Ploeg HP, Chey T, Korda RJ, et al. Sitting time and allcause mortality risk in 222497 Australian adults. Arch Intern Med 2012;172:494-500.

35 Dunstan DW, Howard B, Healy GN, et al. Too much sitting--a health hazard. Diabetes Res Clin Pract 2012;97:368-76.

36 Gilson ND, Burton NW, van Uffelen JGZ, et al. Occupational sitting time: employees' perceptions of health risks and intervention strategies. Health Promot J Austr 2011;22:38-43.

37 Herquelot E, Bodin J, Petit A, et al. Long-Term persistence of knee pain and occupational exposure in two large prospective cohorts of workers. BMC Musculoskelet Disord 2014;15:411.

38 Arcury TA, Grzywacz JG, Chen H, et al. Work organization and health among immigrant women: Latina manual workers in North Carolina. Am J Public Health 2014;104:2445-52.

39 Zhou M, Yang S, Guo Y, et al. Shift work and the risk of knee osteoarthritis among Chinese workers: a retrospective cohort study. Scand J Work Environ Health 2020;46:152-60.

40 Koehoorn M, Demers PA, Hertzman C, et al. Work organization and musculoskeletal injuries among a cohort of health care workers. Scand J Work Environ Health 2006;32:285-93.

41 Carayon P, Smith MJ, Haims MC. Work organization, job stress, and work-related musculoskeletal disorders. Hum Factors 1999;41:644-63.

42 Lee J-G, Kim GH, Jung SW, et al. The association between long working hours and work-related musculoskeletal symptoms of Korean wage workers: data from the fourth Korean working conditions survey (a cross-sectional study). Ann of Occup and Environ Med 2018;30. 